\title{
Community-based initiatives and the politicization gap in socio-ecological transitions: lessons from Portugal
}

\author{
João Morais Mourato a*, Alexandra Bussler b \\ (a) Institute for Social Sciences, University of Lisbon, Av. Professor Aníbal Bettencourt 9, PT \\ - 1600-189 Lisbon, Portugal \\ joao.mourato@ics.ulisboa.pt \\ (b) Institute for Social Sciences, University of Lisbon, Av. Professor Aníbal Bettencourt 9, PT \\ - 1600-189 Lisbon, Portugal \\ alexandra.bussler@ics.ulisboa.pt \\ * Corresponding author. \\ E-mail address: joao.mourato@ics.ulisboa.pt
}

\section{Acknowledgements}

This work was supported by grant SFRH/BPD/73337/2010 from FCT (Fundação para a Ciência e Tecnologia - Portugal) awarded to the first author. We want to express our deepest gratitude to Tim O'Riordan (University of East Anglia), Verónica Policarpo (Institute of Social Sciences University of Lisbon), Gil Penha Lopes (Faculty of Sciences - University of Lisbon) and Lena Pfeifer (PIK - Potsdam Institute for Climate Impact Research) for their insightful comments on earlier versions of this paper. The final version is of our sole responsibility.

\section{Declaration of Interest}

The authors declare no conflict of interest. The opinions expressed herein are those of the authors and do not necessarily reflect the views of the Research Funding Programme of FCT (Fundação para a Ciência e Tecnologia - Portugal), nor of the University of Lisbon. 


\title{
Community-based initiatives and the politicization gap in socio-ecological transitions: lessons from Portugal
}

\begin{abstract}
Community-based initiatives (CBIs) are an embodiment and potential catalyst of societal change towards sustainability. In Portugal, they remain a largely untapped resource. This paper examines different nuances of CBIs' societal change agency by proposing an innovative inquiry framework focused on substance, processes and outcomes via an actor, politics and governance-centered approach. Through an inward- versus outward-looking dialectical reflection on CBIs' politicization dynamics, we analyze Portugal's CBI landscape drawing upon previous research, databases and semi-structured interviews. We conclude that a politicization gap and the absence of both socio-political visibility and of favorable institutional and policy frameworks are crucial contextual premises hindering CBIs' change agency. Notwithstanding, CBI's transformative potential is undeniable. We find them perfectly positioned to mediate co-shaping processes between social innovators and incumbent institutions, contesting the latter's unsustainable development logic. If CBIs and governments acknowledge the complementarity of their scope of societal change agency, CBIs' transformational time may have arrived.
\end{abstract}

\section{Key words}

Socio-ecological transitions; sustainability transitions; community-based initiatives; social innovation; Portuguese community politics; politicization and sustainability 


\section{Introduction}

The current unsustainable relationship between nature and humans has all the signs of critically endangering planetary and human sustainability to the point where the threat of extinction has become a major public concern (Montoya et al., 2018; Steffen et al., 2015; Brown, 2017; IPBES, 2019; IPCC, 2018). The act of confronting this sets a new context for any socio-ecological transition towards forms of living and working based on the practices of sustainability (Rickards, 2015; Olsson et al., 2017; Pel and Bauler, 2014). This paper looks at the potential role of transformative social innovation through efforts towards societal change and policy reforms, understood as a three-sided process comprising: a) substance: addressing unmet social needs, b) process: changing social relations, and c) outcome: bringing about new institutional configurations (Pel and Bauer, 2014).

The growing call for socio-ecological alternatives that radically transform our present actions and systems (Barry and Quilley, 2009; Jackson, 2009; Alexander and Rutherford, 2014) has helped to fuel a substantial increase in the number and variety of community-based initiatives (CBIs). We understand CBIs as "grassroots organizations with innovative ideas which many hope will lead to a transition to a more sustainable society" (cf. Becker et al., 2018: 5). These niche spaces have been widely acknowledged as transition laboratories (cf. Geels and Shot, 2007; Pelling et al., 2008; Göpel, 2016; 2017), where humankind may re-enact its place and relationship within nature and between present and future generations. The pathway to this socio-ecological transition may emerge via the rise of radical niche-innovations and new user practices and institutions inspired by cultural and behavioural changes, with a larger role for civil society actors, social movements, and multi-level governance (Hof et al., n.d.; O'Riordan, 2014).

This mobilization of communities has a significant track record. The concept of community-based can be found discursively and empirically crisscrossing multiple agendas. From localism and local autonomy to nature conservation, circular economy or alternative ecosystem-service valuation discourses, the community has become an indispensable transformative actor worldwide (e.g. Hart and Milstein, 2003). Community-based transformative social innovation is increasingly perceived as key to tackling complex anthropogenic socio-ecological problems in the light of sustainability transitions (Anguelovski and Carmin, 2011; Frantzeskaki and Rok, 2018).

Yet, CBIs' transformative change agency is context-dependent. We argue that it is bound by their politicization dynamics, self-defined objectives, scaling-up strategies and the interaction with both the public sphere and wider institutional surroundings. In particular, we question how the nature of the political and institutional frameworks, in which CBIs are embedded, and their recognition of CBIs' change agency ultimately influences the degree to which CBI's societal change potential may unfold. To inform this discussion on CBIs' nuances of change agency, its drivers, potentials 
and scale-up risks, we examine the Portuguese CBI landscape proposing an actor-, politics- and governance-centred inquiry framework that expands on a novel dialectical inward-looking and outward-looking analysis of their politicization dynamics.

We build on the hypothesis that CBIs remain an untapped resource for socio-ecological transitions and institutional innovation in Portugal. The scarce literature on Portuguese CBIs (Baumgarten, 2017; Esteves, 2017; Fernandes-Jesus, 2017; Marques Balsa et al., 2016; Santos et al., 2016; Rocha et al., 2016) assesses them from a predominantly descriptive standpoint, avoiding reflection on crucial dynamics such as their structure, reach, or possible future socio-economic pathways. Here we analyse the nuances of Portuguese CBIs' engagement with the public and political arenas and examine their potential role as active change actors leading a desired socio-ecological transition towards sustainability. We apply a comparative analysis of both peer-reviewed and grey literature and available datasets on CBIs in Portugal, backed by semi-structured interviews with active Portuguese CBI agents.

The structure of the paper is as follows. Section 2 reviews the pertinent socio-ecological transitions literature. It introduces an analytical framework for reviewing the varied CBI actors' rationales and politicization strategies, proposing a differentiation between an inward- and outward-looking nature. Section 3 provides a descriptive synthesis and critical appraisal of the Portuguese CBI landscape based on existing research, databases and interviews. Section 4 assesses the latter against the background of our conceptual framework on CBI agency for societal change. Finally, in section 5 we outline key conditions (pathways) to further foster the transformative potential of CBIs, and identify perplexing conundrums for future research.

\section{CBI's Agency in Socio-Ecological Transitions}

This section delimits the concept of "community-based initiatives" and guides the reader through selected transition models that try to explain the practices and discourses of transition pathways. It also introduces a theory of change to inform the examination of the linkages between the niche level and its external societal context. Ultimately, this supports our critical analysis of CBIs' societal change agency and politicization dynamics.

\subsection{Niche solutions for a super-wicked problem}

The promotion of a large-scale transition towards sustainability can be understood as a super wicked problem (cf. Lazarus, 2008; Levin et al., 2007). These have four key defining features (Levin et al., 2012):

- Time is running out; 
- Those who cause the problem also seek to provide a solution (i.e. governments perpetuate a dual behaviour promoting policy pathways towards sustainability while allowing its very causes [e.g. fossil fuels exploration and subsidization] to persist);

- The central authority needed to address it is weak or non-existent (i.e. there are no global climate executive authorities);

- Partially as a result from the latter, policy responses routinely ignore the issue of future wellbeing. Therefore, progressive policy coherence over time favouring social and ecological betterment is impossible to achieve and secure.

These four qualities are symptoms of the policy process around sustainability where existent decision-making and governance solutions, available data, and institutional capacity all fall short of providing game-changing solutions. This issue may spring from an unsustainable pathdependency, insofar as present policy and institutional dynamics may inadvertently hinder the future delivery of any meaningful transition to sustainability policies. To avoid this, Levin et al. (2012) advocate a forward-looking perspective, aimed at setting incremental transition pathways towards sustainability, that in turn trigger a domino effect of behavioural changes, which gather support and outreach over time.

This process has multiple echoes in the largely overlapping body of literature including socioecological technical transitions (Geels and Schot, 2007), transition management (Kemp et al., 2007; Rotmans and Loorbach, 2009), sustainability transitions (Markard et al., 2012; Smith et al., 2005) and more recently transformative social innovation theory (Haxeltine et al., 2017). A prominent concept for depicting the systemic multilevel interplay between different societal subsystems across space and time is Geels' Multilevel Perspective (MLP) framework (Geels, 2011). This helps to identify causalities of influence between micro-level actors and macro-level structures that underlie large system change processes. However, MLP depends on a quasi linear assumption of decision-making processes and misses inquiry into the political nature of the sustainability transition (cf. Patterson et al., 2017). The latter reminds of Swyngedouw's (2010; 2011) warning of a "rosy" global de-politicized "environmental consensus". Politics, policies and conflict are inherent in any societal transformational shaping, so their dismissal can inhibit any shift towards sustainability (Prugh et al., 2000; Avelino and Rotmans, 2009; O’Riordan, 2014).

All this feeds a growing perception that governments and international institutions are unable to provide the necessary solutions and subsequent leverage to trigger such transformation (Blühdorn, 2007; Swyngedouw, 2010; 2011). We therefore need to determine who can be the catalysts of change, and how they can better exert their influence.

A significant body of literature (e.g. Geels and Shot, 2007; Olsson et al., 2006; Pelling et al., 2008; Smith et al., 2005; Göpel, 2016) has convincingly argued that socio-technical transformations 
originate mostly at the "niche or micro level, where small units or 'situated groups' experiment easily with alternative solutions, as long as the degree of interdependencies with overarching or neighbouring systems is not too strong" (Göpel, 2016: 22). Like Seyfang and Haxeltine (2012), we understand niches as protected spaces where alternative practices can form and develop, shielded from external system pressures, hosting actors and organizations. A particularly visible niche dynamic is embodied in shielded community-based initiatives, which offer alternative pathways to dominant development paradigms (cf. Haxeltine et al., 2017; TESS, n.d.).

As Göpel (2016: 45) and Minkoff (1997) observe, societal change often springs from alternative or radical socio-political movements that over time manage to gain momentum and mobilize enough critical mass to alter the status quo. Likewise, so can CBIs. These are an elusive and constantly changing set of multidimensional, cross-scale, social-political units or networks of actors (Carlsson, 2000; Berkes, 2004), possible to be framed both as a resource and agent of change. This has already had a visible impact in certain sectors of public policy design and implementation, such as an increasing emphasis on community empowerment and agency, actively engaging key stakeholders in policy co-design, resources co-management, and projects coimplementation (e.g. EU Cohesion Policy - CLLD Community Led Local Development). This, in turn, has started to shift the partnership and participation landscape leading to a growing number of community-led or community-driven development initiatives. ${ }^{2}$

\subsection{Framing CBI's societal change agency}

Societal change is a multi-actor, multidimensional process, which often emerges in unplanned contexts and has unexpected rhythms and mechanisms of diffusion (Mourato et al., 2018). The transition literature still lacks precision when it comes to identifying different types and levels of actors of societal change (cf. Avelino and Wittmayer, 2016), as well as the nature and impact of the relationships between them. In other words, it misses a detailed analytical framework for critically examining the individual and collective dimensions of societal change that give substance to a desired transition to sustainability. To advance this discussion, we take stock of Retolaza's (2011) theory of change. The latter breaks down societal change into four analytical dimensions, reflecting individual or collective, and inward or outward-looking processes.

\footnotetext{
${ }^{1}$ McLeroy et al. (2003) outline a four tier classification where community can be understood as: 1) a setting, mainly understood as a geographical space including community institutions, in physical settings where development interventions are implemented from the top down, and actors are perceived as a sum of community individuals, 2) a target, representing a strategic focus of interventions usually articulated with indicators and benchmarking practices, 3) a resource, translating into the providing of internal 'capital' such as knowledge, traditions or practices, which are valued and integrated in strategic common-ownership, participatory and local decision-making processes that are steered from outside the community, or 4) as an agent, as the inherent force underpinning adaptive, supportive and developmental capacities mobilized via community institutions in order to provide solutions to current community needs.

${ }^{2}$ Community-led, community-driven and community-based are definitions largely used interchangeably and are yet to stabilise in the literature.
} 
Retolaza's (2011) approach allows us to develop an analysis of the substance (i.e. ethos/goals), processes (i.e. underlying inter-actor relations/means) and outcomes (i.e. ends) of CBIs' agency (c.f. Pel and Bauer, 2014) underlying societal change. Adding to McLeroy et al. (2003), CBIs may be potential catalysts, as actors and resources, but also an embodiment of societal change.

\section{CBIs as an embodiment of societal change.}

Transformative Social Innovation Theory claims that CBIs "shape and are shaped by changing social relations and associated institutional dynamics" (Haxeltine et al., 2017: 9). Individual interpretations of sustainability arise out of shared collective understandings through processes of formal and informal socialization (Mourato et al., 2018). In other words, they embody the subjective dimension of individual change in terms of mindset, self-awareness and identity, and subsequently translate into the re-definition of the individual's objective relational habits, practices and dialogical interaction with its social and political environment. This interaction is often conflict-prone as normative systems have a resilience that transcends rebellions and even revolutions (Moghaddam, 2010). We are wise not to underestimate the power of cultural norming. For it is in face of such power that CBIs seeking socio-ecological transitions have emerged and proliferated. CBIs are then the objective embodiment of a multitude of subjective individual processes of change triggered by agonistic stances to predominant normative sustainability values and worldviews.

\section{CBI's as a potential catalyst of societal change}

CBIs can be understood as 'active minorities' (cf. Moscovici, 1979), which instead of transforming society from within its institutions, or by taking up state power, focus on building up equivalence between social demands to create new social awareness (Laclau and Mouffe, 1985). In this sense, CBIs aggregate individuals who aim to further their individual transformative change through collective action, often in niche-level small units or 'situated groups' (Göpel, 2016:22). This intersubjective dimension of CBI-led societal change builds on the definition of a collective identity and subsequent patterns of collective action (e.g. vegetarians teaming up to promote vegetarian values). However, here lays a major analytical crossroads regarding different interpretations and expectations of the role CBIs may play in a wider societal change.

Göpel (2016:47; 22) argues that the niche-level interdependencies with neighbouring systems may severely hamper CBIs' potential as spaces of social innovation. Yet, there is no definite evidence that isolation is a precondition for social innovation towards sustainability. Notwithstanding the merits of Göpel's argument, its premise of self-imposed isolation begs the question of how exactly can CBI's niche social innovation dynamics influence, or trigger, alternative pathways to dominant development paradigms or regime changes (cf. Geels and Schot, 2007). 
To this effect, Haxeltine et al. (2017) argue that wider regime change springs from CBI-related innovation and their intertwined social relations and associated institutional dynamics underpinning the latter. This theory places CBIs, their actors and networks as a manifestation of social innovation, that "shape and are shaped by changing social relations and associated institutional dynamics" (Haxeltine et al., 2017: 9) in a reciprocal relationship, thus, engaging the interobjective dimension of societal change.

A controversial issue in this rationale is the scaling-up of CBI's transformative practices, in the sense of setting transition pathways. Scaling-up is primarily not about growing in a literal sense, but about setting transition pathways. If the scale of these initiatives and their practices are too small, they will never constitute a truly visible and validated alternative to the growth-driven economic paradigm, unable to decolonize the predominant societal mind-set so ultimately help trigger a system change. In this sense, Henfrey and Penha-Lopes (2018) argue that if niche CBIs are to help trigger wider societal change, they need to make their ideas and practices visible, introduce them into the public debate, ultimately facilitating their wider societal acceptance and action. They also suggest that CBIs must further engage in transition politics, even if it implicates an opening of their 'protected niche space' (cf. Seyfang and Haxeltine, 2012).

\subsection{Politics and Politicization of CBIs}

Societal transition cannot be decoupled from an analysis of the power dynamics at play when it comes to regime change. Transition's power dynamics shift and realign along the way, triggered by "conflicts, power struggles, contestations, lobbying, coalition building, and bargaining" between the regime actors and the incumbent groups (Avelino and Wittmayer, 2016: 631). In this context, it is important to examine how CBIs access and exercise power in transition processes and to what extent this power is shifted from the situated regime to these niche actors.

To this effect we must examine CBIs politicization dynamics. Politicization means neither the juxtapositions of specific agendas with politics, nor the increased interest in politics among certain social movements or communities. Politicization identifies a phenomenon as political as an arena for contingent action (Palonen, 2003). In other words, there is no politics before politicization, either in a logical or a temporal sense. And when an established political arena and polity exist, politicization either introduces new items to it, which alter the relationships between the existing ones, or dismisses existing items (ibidem). This argument helps us make sense of CBIs' political agency and their potential role as catalysts of societal change.

All CBIs share a fundamental utopian leitmotif of societal change. A comparative study of 63 CBIs in Finland, Germany, Italy, Romania, Scotland, and Spain identified a set of internal (e.g. will to break the inherent unsustainable status quo; shared identity and values with participants) as well 
as external (e.g. the dominant system fails to satisfy socio-environmental needs and local empowerment; existence of a socio-political vacuum) factors that determined the motivation of their emergence. Yet there is no universal landscape of CBIs as spaces of social innovation. Despite their shared goal, not all can, need or choose to follow, a 'head-on' strategy of engaging with the system. Some fear "being co-opted, or being taken over by the corporate sector or higherlevel governance" or doubt "the capacity of top-down policies to spark a real transition to a sustainable society on their own" (Hof et al., n.d.: 8). In addition, Holsten et al. (n.d.: 14) discussing European CBIs state that "collaboration with public institutions are mixed: some members feel that they fill an institutional gap and hence complement public institutions; others fully abstain from such interactions. Third groups try to do a bit of both". Thus, just like transition pathways, CBIs politicization options and strategies are neither sequential, nor linear processes of societal change.

Hence, despite their shared value framework, CBI's agency reflects a wide array of politicization dynamics that range from inward-looking to outward-looking. This conceptual classification, inspired by Retolaza's (2011) theory of change, builds on the extent to which the nature of a CBI's action towards societal change is intersubjective (i.e. focused on the change of collective identity and subsequent patterns of collective action), or interobjective (i.e. institutionalization of change via the transformation of structures, institutions and procedures). Inward-looking and outwardlooking politicization dynamics should thus be understood from a dialectical, rather than dichotomic standpoint. Choosing to remain inward-looking is a political act per se, insofar as it either arises from antagonistic opposition to the current development system or as an intentioned confinement to a very limited social and local radius of influence.

While we acknowledge the undeniable value of a pluralistic CBI politicization landscape, we find that predominantly outward-looking CBIs remain an untapped resource for socio-ecological transitions and institutional innovation. CBIs' coherent commitment to discourse formation around the need for specific changes to existing institutions, network formation, favouring reflexive advocacy, lobbying, and protesting in response to ongoing changes in circumstances, set the stage for challenging dominant institutions and institutional logics (cf. Haxeltine et al., 2017). In turn, this requires balancing the opposed forces of independence from versus accommodation to existing systems (e.g. social credit cooperatives have to find their place in the existing banking institutions framework, while balancing their values to transform the very same), as well as 'institutional bricolage', that is, using existing institutions and resources in novel ways, or even creating new ones (e.g. local currency or community-supported agriculture) (ibidem).

\section{Portugal's CBI landscape}


At the turn of the century, Portugal still had one of the lowest levels of societal mobilization concerning any recognizable form of sustainability transition in Europe (Schmidt et al., 2006). However, available data hints at a country-wide growth tendency of CBIs since 2010 (Marques Balsa et al., 2016), with little by way of an accurate quantification of that increase. Transitions to sustainability remain largely absent in Portugal's public debate (Baumgarten, 2017). Nevertheless, the socio-institutional landscape towards sustainability transitions in Portugal is changing, largely due to a growing number of action-research projects (e.g. ClimAdaPT.Local; CATALISE; PROSEU) and community-led bottom-up initiatives (e.g. the CBIs Fruta Feia; Trokaki; Cooperativa Verde Perto). ${ }^{3}$ All of these focus on either leveraging or implementing sustainability in various contexts.

\subsection{Introducing Portuguese CBIs}

In a thorough review of both international and national literature, academic and non-academic, including dissertations at the doctoral and master's level, as well as bottom-up organized databases and grey literature, we confirm a scarcity of data on Portuguese CBIs. Our analysis builds on three project databases that represent the majority of the information available on the Portuguese CBI landscape. The databases are: 1) CATALISE - a national research project that looked into Portuguese CBIs from an overarching perspective; 2) Rede Convergir - the biggest national network hub for CBIs, and 3) ECOLISE, a European coalition bringing together national and international networks of CBIs, as well as organizations supporting community-led transition. ${ }^{4}$

The diverging database configuration and CBI definition of these sources limit, but do not negate, comparative analysis. Methods-wise, we conducted a comparative content analysis of these databases and other published outcomes and reports. We systematized our analysis in a comparative table (see Annex 1 of the Appendix). This was backed by a set of semi-structured

\footnotetext{
${ }^{3}$ For more information see Table 1.

${ }^{4}$ 1) CATALISE identified a total of 471 CBIs (2015/2016), contacted each individually and then carried out a detailed questionnaire on all 84 respondents (Marques Balsa et al., 2016: 33). It used subnational thematic networks (e.g. social development) and forums, including Rede Convergir, as data sources, using wide-ranging classification categories (i.e. social intervention, economic project or environmental project) that failed to help navigate CBIs' high degree of heterogeneity. This lack of data organization translated into a fragmented and non-user friendly database, compromising their findings. The overrepresentation of CBIs from specific thematic networks, such as 'social economy', in CATALISE's database make some thematic areas appear falsely predominant, disguising the actual functional distribution on the ground. This may, however, spring from the acknowledged emphasis of CATALISE's funding body (Gulbenkian Foundation) on the social issues of CBIs. 2) Rede Convergir, a 'decentralized, open-access visualisation tool', mapped a total of 204 initiatives who voluntarily and independently registered on their webpage, for which it can be seen as an actual bottom-up initiative (Avelar et al., 2018). This suggests that Rede Convergir better reflects the actual active CBI landscape in Portugal. Nevertheless, it is possible that only a fragment of the real number of CBIs joined Rede Convergir, due either to unawareness of the existence of the network, or a legitimate will to remain somewhat 'off the grid'. 3) ECOLISE builds their database on information from transnational and subnational networks, such as the Transition Network or Rede Convergir. This may justify the similar mapping outcomes on their interactive map as in Rede Convergir: 171 CBIs (2018).
} 
interviews with some of the researchers that double as active agents within the Portuguese CBI landscape, in order to collect first-hand information on the setting-up and development dynamics of CBIs in Portugal.

The main leitmotif of Portuguese CBIs is their acknowledgement of the shortcomings of the predominant contemporary socio-economic system, and the consequent need to foster local resilience and action through socio-ecological change. Sustainability, climate change, social inequality and vulnerability are the main thematic mobilization banners (Marques Balsa et al., 2016), with no reference to the socio-economic crisis of 2009-2010 (Baumgarten, 2017).

They have very specific and diverging action focuses, ranging from earth and nature management to change in agricultural practices, health and wellbeing, culture and education, technology and construction, social organization, economy and finance, and so forth (Marques Balsa et al., 2016; Rede Convergir, n.d.). This high diversity may explain why the three aforementioned databases don't share a basic common understanding of how CBIs can be classified thematically and in terms of scope of action.

CATALISE and Rede Convergir both subdivide CBIs into 10 categories, of which three overlap: Permaculture, Transition, and Economic and Finance. ECOLISE offers a narrower 4-type classification (Permaculture, Transition, Eco-villages and Other). In Rede Convergir, most CBIs fall under the categories of Nature and Earth Management (e.g. urban gardening, neo-rural settlements), Permaculture, Education, Community and Commons (e.g. eco-villages) or Transition initiatives (Avelar et al., 2018). In turn, the majority of CBIs in CATALISE fit the category of Social Intervention (e.g. education, formation/capacitation, employment creation and community development) (Marques Balsa et al., 2016). In ECOLISE (n.d.), a large majority (105) of CBIs is categorized as Other, ranging from education-, arts-, and agriculture- to solidarity-related initiatives, followed by Permaculture (38). Despite this heterogeneity, certain patterns emerge: most CBIs seem to be nature- and permaculture-related and have a social focus.

Furthermore, combining the geo-spatial data from our three sources we identify four regional geographical clusters: A) Northwest Portugal (predominantly eco-villages and permaculture), B) the triangular area between Coimbra, Santarém and Castelo Branco (mainly eco-villages, transition and permaculture, C) Lisbon's Metropolitan Area, Sintra's municipality in particular, with the major concentration of diverse types of incentives, and finally D) the Alentejo and Algarve coast (mainly eco-villages) (see Figure 1).

\footnotetext{
${ }^{5}$ For the detailed classification matrices see Annex 1 of the Appendix.
} 


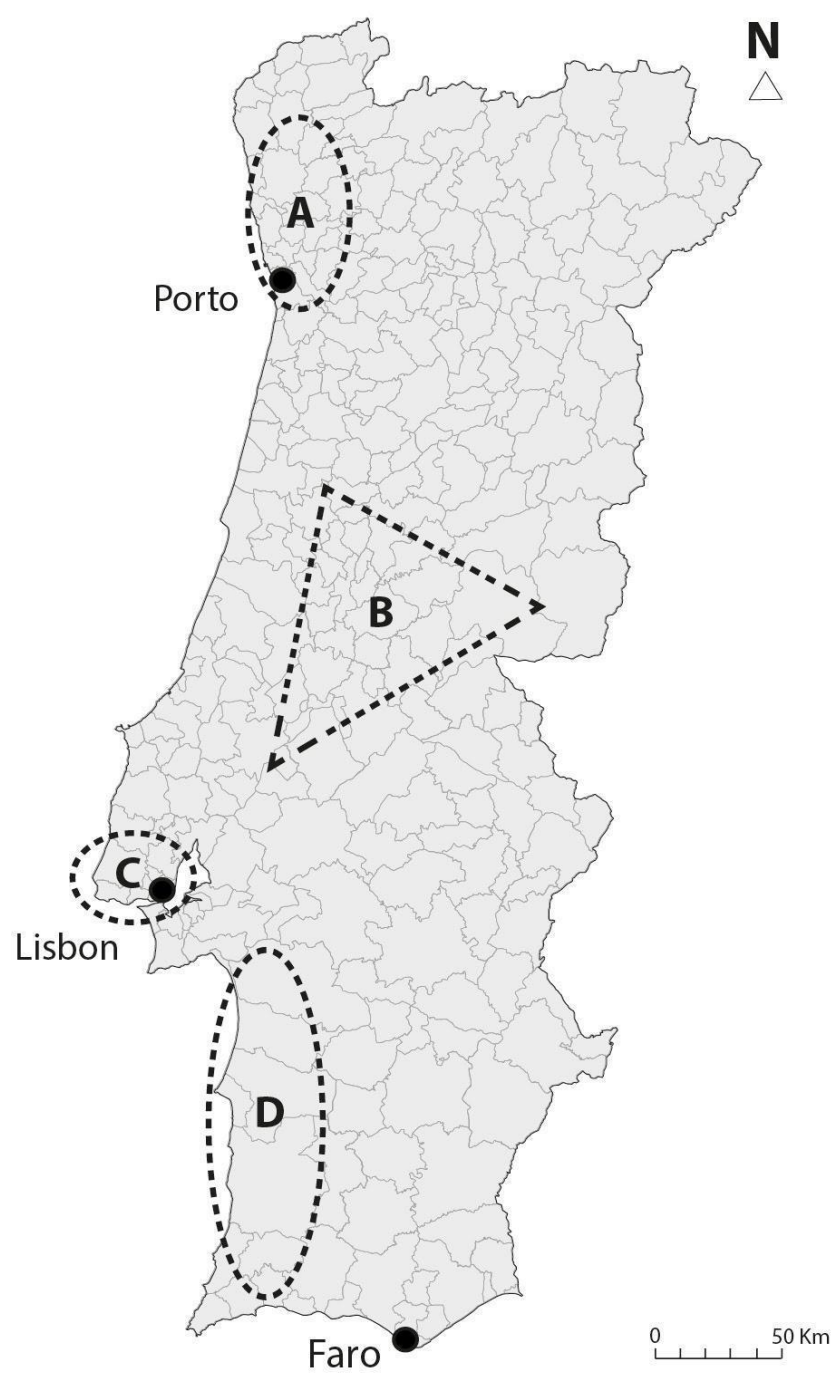

Figure 1-Portugal: Regional CBI geographical clusters

In order to assess the degree of resilience of Portugal's socio-ecological transition landscape, it is important to look at CBIs' longevity. There seems to be a low survival rate after the first few years of existence and most of the CBIs still seem to find themselves in a development phase. The majority of initiatives have run for 3 to 5 years, while only $25 \%$ have operated for more than 7 years (cf. Marques Balsa et al., 2016: 35; Baumgarten, 2017). Other research on European CBIs (Tess, n.d.) showed that survival over time is affected by factors such as their relation with governments and institutions or the adopted organizational structure. 
To understand the features of this landscape, it is relevant to take a closer look at the actors driving the creation and management of Portuguese CBIs. CATALISE informs us that more than half the CBIs were founded by multiple partners, a term left ambiguous. The average of people "taking part in CBI activities" is around 1500 per year. Nevertheless, a critical scrutiny reveals a median of 108 and a mode of only 10 participants (Marques Balsa et al., 2016: 38; 42). This indicates a large disparity in the participation structure insofar that a small number of CBIs aggregate a lot of participants while the majority hosts a limited amount (i.e. around 10). A great number of initiatives are founded and steered by expatriates, especially in the rural areas (cf. Leal, 2014), as exemplified by the Tamera eco-village and healing centre in the Alentejo region, the most prominent Portuguese CBI. The founders and the great majority of the around 170 permanent inhabitants are non-Portuguese, mostly from Austria, Germany and Switzerland, while the rest stem from other European or Western countries. Only seven members are native Portuguese (cf. Esteves, 2017). CBIs are promoted by individuals with a significantly higher educational level than the average population, often belonging to the academic milieu (see for example Marques Balsa et al., 2016: 80 or Campos et al., 2016). Furthermore, the managers of the projects Rede Convergir, CATALISE and ECOLISE all include members of the CCIAM research group of the Faculty of Sciences of Lisbon University?

A key actor in the Portuguese CBI landscape (Vizinho, personal communication, May 15th, 2018) related the challenge of CBI's resilience to the capacity and willingness of its members to integrate into local culture and participate in local governance (cf. Rocha et al., 2016). In this line, the degree of local entrenchment would represent a crucial element in assessing the potential societal impact of CBIs as promoters of socio-ecological transitions towards sustainability. In Portugal, however, we discover a limited level of local entrenchment, as discussed in section 4 .

\subsection{A fragmented CBI landscape}

The purpose of Portugal's CBIs is to 'repair' the deficiencies of the incumbent socio-ecological paradigm by rethinking and reinventing 'development' via local action that embodies divergent (e.g. eco-villages) or complementary (e.g. Transition movement) alternatives. Their aim is to forward a new value system based on solidarity and social cohesion, community building, proximity (locality) and direct interaction, active involvement, citizenship, responsibility sharing, participative governance and self-management, in order to promote just and sustainable development (cf. Santos et al., 2016; Rocha et al., 2016). Table 1 introduces a set of CBI examples in Portugal.

\footnotetext{
${ }^{6}$ See Table 1 for a detailed description.

${ }^{7}$ See Annex 2 of the Appendix for a detailed description.
} 


\begin{tabular}{|c|c|c|}
\hline Trokaki & $\begin{array}{l}\text { A local exchange trade system (LETS) that englobes a } \\
\text { market where goods, time and services can be } \\
\text { transformed into credit that in turn can be exchanged for } \\
\text { other goods, time or services. It is mainly active in Lisbon }\end{array}$ & https://www.facebook.com/Trokaki/ \\
\hline Verde Perto & $\begin{array}{l}\text { A local producers' cooperative situated in the district of } \\
\text { Santarém specialised in local food supply chains and local } \\
\text { development via formation (e.g. permaculture), rural } \\
\text { accommodation or volunteering activities }\end{array}$ & https://www.verdeperto.pt \\
\hline Fruta Feia & $\begin{array}{l}\text { A sustainable retail cooperative that engages in saving } \\
\text { food from local farmers that does not correspond the } \\
\text { market requirements in terms of shape. Currently, it has } \\
\text { delegations in more than } 8 \text { cities in Portugal. }\end{array}$ & https://www.frutafeia.pt \\
\hline Coopérnico & $\begin{array}{l}\text { Coopérnico is a } 2013 \text {-funded first Portuguese prosumer } \\
\text { cooperative of renewable energies. }\end{array}$ & https://www.coopernico.org/en/ \\
\hline Tamera & $\begin{array}{l}\text { Tamera is a } 200 \text {-inhabitant eco-village in the Alentejo } \\
\text { region, with the mission to create a world beyond war by } \\
\text { building "Healing Biotopes", } \\
\text { futuristic centers that research and model a new planetary } \\
\text { regenerative, nonviolent culture. }\end{array}$ & https://www.tamera.org/ \\
\hline $\begin{array}{l}\text { Amoreiras Village } \\
\text { Convergence Centre } \\
\text { (ACC) }\end{array}$ & $\begin{array}{l}\text { ACC was a holistic local development project (2006-10), } \\
\text { aimed at creating a sustainable village through the } \\
\text { participation and empowerment of the local community, } \\
\text { integrating economic, ecological, social and personal } \\
\text { components. }\end{array}$ & $\begin{array}{l}\text { https://transitionnetwork.org/transition- } \\
\text { near-me/initiatives/aldeia-das- } \\
\text { amoreiras-sustentavel/ }\end{array}$ \\
\hline
\end{tabular}

Table 1-CBI examples in Portugal

We witness a non-networked set of heterogeneous initiatives with a plurality of agendas and highly diversified thematic emphases, ranging, for instance, from education, social and solidarity economy, bio-construction, agriculture to spirituality. They are largely in their embryonic development stage or short-lived. This fact is particularly relevant when taking into consideration the overall recent appearance and growth of the CBI phenomenon. Yet, we have no means to determine whether the latter implies a 'false start', where CBIs fail to transform into proper initiatives, if they simply take a long time to set up, or if they are transforming or even travelling across space or institutional settings. This intersubjective process of CBIs' development defines their collective identity, their leadership structure and subsequent patterns of collective action. This is a fundamental determinant of their resilience, which in turn enhances their scale up potential, since over time they are able to build up and strengthen necessary internal and external structures (i.e. networks).

In line with other studies on CBIs (e.g. TESS, n.d.; CATALISE, n.d.), we identified that the continuity of leaders appears to be a determinant factor for CBIs' overall societal impact and resilience, especially given that fundamental roles seem to concentrate in a limited number of

\footnotetext{
${ }^{8}$ Find more details in Annex 1 of the Appendix.
} 
individuals. These actors (e.g. the CCIAM research group members) seem to be catalyzing multiple initiatives in Portugal throughout time and space. This multi-role effect (i.e. moving between science, CBIs and activism) may result from the engaged scholarship practiced by these academics, and the action-research projects that they develop.' The latter is however not without controversy. These overlapping roles could misrepresent actual CBI dynamics and their resilience, as the high dependency on a few key actors could undermine their survival and institutional robustness. In addition, the fact that people with higher than average levels of formal education seem to prevail in CBIs, risks excluding people from other ethnic, demographic or socio-economic backgrounds. This may reproduce those patterns of social and economic privilege that CBIs' values originally rejected (cf. Smith et al., 2016; Argüelles et al., 2017).

\section{The Politicization Dynamics of Portuguese CBIs}

Taking stock of Retolaza's (2011) theory of change, our discussion on CBIs actors' inwardlooking and outward-looking rationale (section 2) and the evidence explored (section 3), this section examines the extent of Portuguese CBIs' agency towards socio-ecological transition. We suggest that the Portuguese CBI landscape features a lack of local entrenchment. The following subsections explain this reasoning in detail.

\subsection{The inward-looking niche}

We identify a mismatch between some of CBIs' discursive manifestos and their practices. Despite calls for wider societal transformation as a fundamental part of their leitmotif, not all CBIs actively choose to scale-up and interact with the outer world. From a conceptual standpoint, this inwardlooking niche has two dimensions.

On the one hand, there are inward-looking CBIs with no intention of expanding their reach. Despite a wider societal change towards sustainability being fundamental for them, they would rather confine to specific independent local-level actions, engaging local communities and institutions (cf. Smith et al., 2016). Fruta Feia is an example here due to their self-imposed delimited local reach, connecting exclusively with local actors and local institutions, and their specific focus on reducing food waste from local agriculture.

On the other hand, there are CBIs that are inward-looking as a reflection of an antagonistic stance towards prevailing societal structures (cf. Smith et al., 2016; Celata and Coletti, 2018). These promote societal isolation because they believe that total autonomy and self-determination from a perceived discredited incumbent capitalistic system, is a fundamental condition to exist, survive and thrive. These CBIs evolve with a closed member structure and with restricted interaction with

\footnotetext{
${ }^{9}$ Such as: PLACARD, Adapt for Change, BASE (see Annex 2 of the Appendix for further information).
} 
local residents or institutions, based on allegedly cultural or institutional factors (e.g. resistance to change; a closed culture of local population; centralistic state behaviour; excessive procedure normalization; and over-complicated rules for organization formalization (Rocha et al., 2016)). This phenomenon of 'unreflexive localism' may derive from a perfectionist utopian vision of true sustainable local living based on a set of normative predetermined simplified ideas (cf. Dupuis and Goodman, 2005). This segregationist stance often translates into mute coexistences between CBI actors and local communities. Examples for the latter could be the numerous eco-villages across the country, such as Tamera, that seem to seek partial to total isolation and self-sufficiency motivated by the desire to 'decouple' from the current socio-economic paradigm and create autonomous 'new systems'.

In hindsight, this desired withdrawal may seem a valid short-term solution to avoid conflict and secure the survival of the CBI, namely on initial settlement stages when CBIs' values or lifestyle choices may bring about some cultural clash with local communities. This is reflected by the fear of co-optation from the corporate or public sector and the scepticism towards top-down approaches to societal transitions (Hof et al., n.d.). However, in the long run, the denial of the politics of the local hinders cultural acceptance and the potential of CBIs' development impacts (cf. Rocha et al., 2016). This risk of social exclusion and 'ivory-tower thinking' has already been signaled. Among others, Fernandes-Jesus et al. (2017: 1550) argue that there is for example an inherent difficulty in the Portuguese Transition movement to mobilize beyond highly educated, "post-materialist progressive" individuals that have both the resources and willingness (consciousness) to engage in environmental activism.

\subsection{The outward-looking niche}

Conversely, there is a growing number of CBIs recognizing the fundamental significance of the pro-active promotion of local community engagement, involvement, and first and foremost knowledge exchange, networking and cooperation (even if only horizontal) as a basic condition to evolve (cf. Campos et al., 2016). These outward-looking CBIs believe in and aim for scale-up, expansion and transferability of social innovation practices within the wider context of socioecological transitions, but often don't know how to do it, or lack instrumental resources to achieve it (Santos et al., 2016). Therefore, it is possible to disaggregate them into two groups: those who are actively seeking and achieving a 'dialogical' (cf. Celati and Coletti, 2018) relation with the inter-objective dimension of societal change (e.g. political institutions), and those who, despite having a similar intent, are unable to do so. Mostly, this is due to encountering "resistances [...] to place changing practices" by "the faceless realms of technical government and administration [...]" (Mason and Whitehead, 2012: 509). An example for the latter type of CBI is the first bottom-up Portuguese energy cooperative Coopérnico ${ }^{10}$ which, since its foundation in 2013, turned into a

\footnotetext{
${ }^{10}$ For more information see Table 1.
} 
recognized player in the public debate on energy. Yet, its hope for scale-up towards becoming a valid alternative for energy provision on a local scale is impeded by administrative, legal and bureaucratic hurdles.

\subsection{Hidden connections}

Inward- and outward-looking CBIs may differ in the formalization and pursuit of their relational strategies (i.e. isolation or networking) and thus societal change agency (Section 2). However, their interaction with the 'outside world' already exists, and in some cases even reaches structural levels. For example, the idyllic portrait of small and isolated self-sufficient eco-villages, theoretically independent (e.g. from energy, schooling or medical supply), is somewhat a fallacy: sooner or later - often systematically - they will create interdependency bonds with the incumbent system.

For inward-looking CBIs, these interactions are often guided by a self-justifying rationale of using the capitalistic system and its structures for the CBIs' good. This informs a predominantly instrumental relationship with the political and economic spheres, for instance in order to acquire sufficient funding for their development and survival. Take for instance Tamera: several of its members spend the summer months in Northern Europe working in temporary jobs in order to provide sufficient funds for the project to survive over the rest of the year (Esteves, 2017). Similarly, the Amoreiras Village Convergence Centre (ACC) in Odemira initially brought in five people with a one year work-contract while others arrived as volunteers, using their own financial resources, hoping that the ACC would eventually create jobs. Such employment had to result from the individual or collective entrepreneurship and was often not enough, due to several factors namely the low density population and the time dedicated to non-marketed services such as local development activities. Since employment in ACC was only possible for short-term periods, most members had to find ways of earning money outside (Vizinho, personal communication, May 15th, 2018). This is another example of a CBI survival strategy that inadvertently strengthens its dependency on the overall socio-economic system whose dysfunctions mobilized it in the first place. From a more orthodox standpoint, this instrumental interaction with the system may seem to compromise the "purity" of their founding values (Haxeltine et al., 2017: 10), such as locality, solidarity or equality. But it may also be perceived as much needed pragmatism to enable CBIs to continue to function.

\subsection{The politicization dynamics of Portuguese CBIs}

CBIs' practices and their sustainable transition discourses are still invisible in the Portuguese media, public or political arenas (i.e. outside their communities of practice) (Baumgarten, 2017). Portuguese CBIs are yet to fully embrace their transformative agency favouring the replication and scale-up of their practices, ideas, and values. In fact, they seem to operate outside the public realm 
and their politicization dynamics have yet to significantly influence the Portuguese policy agenda. A large amount of CBIs monitored by CATALISE focus on the horizontal transferability of knowledge (i.e. replication and collaboration) instead of engaging in upscaling and organizing their efforts in order to build up momentum for a bigger change (Rocha et al., 2016: 22).

On the one hand, this might reflect CBIs that foster a more isolationist philosophy, motivated by a political decision from a protest standpoint (e.g. due to lacking funding or scale-up solutions). On the other, it might be the outcome of a lack of means for the CBIs to create a desired interaction with their surroundings (e.g. lack of participatory mechanisms or institutional barriers) (cf. Smith et al., 2016). In effect, CATALISE's policy recommendations claim that CBI's transformative agency depends largely on the exterior context (e.g. cultural norms and practices) and on the existing system and its structures (e.g. public policies, legislation, funding possibilities) (Rocha et al., 2016). Yet, only a deeper analysis into CBI actor's motivations could ultimately define their nature.

The current Portuguese CBI landscape offers multiple interpretational approaches in terms of societal change agency (section 2) and interaction with public institutions and local communities. Independent of CBI's politicization rationales, dedicated champions, knowledge and policy brokers that focus specifically on enabling their interaction with the private and public economic, political and institutional spheres (i.e. policy-makers and polity, other CBIs, and society at large) are needed. This accounts for all forms of CBIs that want to champion wider societal change towards sustainability.

\section{Final remarks}

CBIs are both an embodiment and a potential catalyst of societal change towards sustainability. In this paper, we have contributed to the transition literature by proposing a new framework of inquiry into the different nuances of CBIs agency, in terms of substance, processes and outcomes. We then applied this lens to the Portuguese CBI landscape and undertook a dialectical reflection of its inward-looking and outward-looking politicization dynamics.

Taking into consideration their change potential, we see three possible scenarios for the future of CBIs, independent of their geographical location. The first is their steady atrophy and consequent extinction, as the key actors driving them forward either lose heart or run out of resources, in face of the resistance to change of the dominant regime. The second is a bittersweet one where CBIs will linger on in somewhat similar variations of their current nature, nevertheless remaining solely a laboratory of social innovation alternative practices and simultaneously an untapped resource for wider societal change. The third scenario is that this CBI-related potential for social innovation is sufficiently acknowledged by existing institutional structures to allow its entry, either through the 
creation of specific CBI support structures, or a simple adaptation of already existing policy solutions.

There are two major ways in which this third scenario may materialize. Existing institutional infrastructures take the lead and act as a catalyst for the inclusion of CBI social innovation into the wider system. Or CBIs start to mobilize and claim to give their input towards a wider socioecological transition via the existing institutional infrastructure. The first of these options seems unrealistic at present. The spotlight falls therefore on the second pathway. In a nutshell, in the Portuguese case, we feel that CBIs must gain political voice, that is, express their views and influence policy and decision-making processes. And to do so, two key obstacles must be tackled head on.

Socio-political visibility. Portuguese CBI dynamics show that although they have been gaining ground in numbers and diversity, both inward-and outward-looking CBIs remain largely invisible to the public eye. For CBIs aiming at a wider societal influence, this mirrors a certain dispersion and lack of networking and politicization, which in turn prevents them from fully embracing their potential to advance the replication and scale-up of their practices, ideas, and values via turning into political and visible active change actors and champions for a socio-ecological transition towards sustainability. What we observe today are the first avant-garde efforts of collaboration, replication and embeddedness with a potential yet to be explored. In this pioneering context, our analysis of CBIs' agency must lie on process rather than outcome. Although the on-the-ground practices of Portuguese CBIs have had limited impact in changing current development paradigms, they may well have had many non-quantifiable influences. These refer to spaces of social engagement and experimentation, lifestyle changes, awareness raising and so forth, that can be found for instance in those CBIs with limited but nevertheless equally pertinent action focuses. This may be the case with the growing alarm and engagement between young people and communities/governments which has every sign of intensifying. Dismissing the latter would be unwise, as CBIs represent the first stepping stone of a generation of practices that might evolve, through trial and error, into viable alternatives to the global dominating growth-oriented development paradigm and its inherent multidimensional unsustainability.

Policy role. CBIs are perfectly positioned to act as pathfinders of co-shaping processes, between social innovators and incumbent institutions, actively contesting the latter's unsustainable development logic in the relevant political fora. Yet, they are unlikely to achieve this without favourable institutional frameworks and policy environments. This implies that governments must acknowledge CBIs' roles and achievements, both of the inward-and the outward-looking ones and be willing to share responsibilities with those CBIs that actively seek to champion societal change. Instead of acting solely as regulators, governments can themselves become innovators and facilitators. It is as if CBIs and governments are yet to fully acknowledge the complementarity of their scope of agency in societal change. CBIs can potentially contribute in multiple local policy 
contexts. For example, they can help mitigate the lingering negative impacts of the 2007-08 economic crisis in sparsely populated areas or revitalize ageing rural territories in a growingly urbanized Europe. Particularly in deprived and growingly depopulated areas, they can serve as a deterrent for a local break-down in social cohesion. Alternatively, CBIs are potential players for the local achievement of the 2030 Sustainable Development Goals that resources-strapped municipalities should consider. Once again, the emerging mood of awareness and anxiety being expressed amongst young people across the world may help to spurt rapprochement across governance where rejuvenated CBIs could well play a catalytic role.

Linked to this is the troublesome question of political and social representativeness. We have noted above that the membership of the overwhelming majority of Portuguese CBIs is of a narrow social and ethnic composition. As Portugal searches for political inclusivity in its quest for sustainability, this aspect requires special attention in the coming stages of the outward and widening roles of CBIs in all transitional movements.

We come full circle. Why is outward-looking politicization necessary? As Avelino and Wittmayer (2016) point out, sustainability transitions are closely intertwined with long-lasting socio-political change. When reflecting on the potential role CBIs can play in mobilizing such change, we find a fundamental politicization gap. We believe that outward-looking, inter-objective politicization, as a process, is in itself an under-explored transition pathway that should develop alongside with current CBI practices in Portugal and elsewhere. The latter could materialize as follows: 1) engaging in relations and forming coalitions and social networks with other initiatives across space and action-focus, 2) engaging with the political environment, such as (local) governments or the public sphere, and sub-political actors of their closer surroundings. In light of the scarcity of detailed literature and data on Portuguese CBIs, an exciting future research avenue entails an indepth qualitative study of the underlying ethos that motivate CBIs and their actors to engage in their practices and politicization strategies. We should bear in mind that the world is becoming demonstrably a more frightening place. The societal innovation potential of CBIs may well provide the democratic bridge over which beleaguered governments the world over are more and more willing to cross. Their transformational time may well have arrived. 


\section{Appendix}

Annex 1: CBI classification according to the three databases ECOLISE, CATALISE and

Rede Convergir

\begin{tabular}{|c|c|c|}
\hline CATALISE & REDE CONVERGIR & ECOLISE \\
\hline \multicolumn{3}{|c|}{ Category* } \\
\hline $\begin{array}{l}\text { Permaculture } \\
\text { Transition Towns } \\
\text { Social Intervention } \\
\text { Social Enterprise } \\
\text { Economic Project } \\
\text { Holistic Project } \\
\text { Eco-village/Community } \\
\text { Environmental Project } \\
\text { Holistic School } \\
\text { Other }\end{array}$ & $\begin{array}{l}\text { Permaculture } \\
\text { Transition } \\
\text { Community and Commons } \\
\text { Built Environment } \\
\text { Culture and Education } \\
\text { Economy and Finance } \\
\text { Nature and Earth Management } \\
\text { Tools and Technologies } \\
\text { Health and Spiritual Well-being } \\
\text { Other }\end{array}$ & $\begin{array}{l}\text { Permaculture } \\
\text { Transition Initiatives } \\
\text { Eco-villages } \\
\text { Other }\end{array}$ \\
\hline Areas of intervention & Areas of interest & (no equivalent) \\
\hline $\begin{array}{l}\text { Education } \\
\text { Formation / capacitation } \\
\text { Community development } \\
\text { Employment creation } \\
\text { Social and solidarity economy } \\
\text { Agriculture/horticulture } \\
\text { Stock farming } \\
\text { Communication / dissemination } \\
\text { Health } \\
\text { Spirituality } \\
\text { Bio-construction } \\
\text { Renewable technologies } \\
\text { Environmental questions } \\
\text { Network development } \\
\text { Arts and culture }\end{array}$ & $\begin{array}{l}\text { Education } \\
\text { Alternative Economics } \\
\text { Social tools } \\
\text { Agriculture } \\
\text { Stock farming } \\
\text { Land / tools sharing } \\
\text { Health } \\
\text { Spirituality } \\
\text { Bio-construction } \\
\text { Eco-technology } \\
\text { Arts }\end{array}$ & - \\
\hline
\end{tabular}

*Categories in italics have a correspondent in one or all of the three databases

\section{Annex 2: Listing of transition-related actors and actions}

\section{TSI related research and research projects}

TSI

(Transformative social innovation)
TSI theory was informed by empirical findings of three major research projects on cross-country CBIs 


\begin{tabular}{|c|c|c|}
\hline & $\begin{array}{l}\text { in Europe. These research projects are: TESS, } \\
\text { PATHWAYS, ARTS and DRIFT. }\end{array}$ & \\
\hline $\begin{array}{l}\text { TESS } \\
\text { (Towards European Societal } \\
\text { Sustainability) }\end{array}$ & $\begin{array}{l}\text { With the aim to explore the role of community- } \\
\text { based initiatives (CBIs) in creating a sustainable, } \\
\text { low-carbon Europe, led by the Potsdam Institute for } \\
\text { Climate (PIK). }\end{array}$ & $\begin{array}{l}\text { http://www.tess-transition.eu/resources- } \\
2 /\end{array}$ \\
\hline $\begin{array}{l}\text { PATHWAYS } \\
\text { (Transition Pathways to } \\
\begin{array}{l}\text { sustainable } \\
\text { societies) }\end{array}\end{array}$ & $\begin{array}{l}\text { Led by the PBL Netherlands Environmental } \\
\text { Assessment Agency and aiming at providing } \\
\text { policy-makers and other key stakeholders with } \\
\text { better insight in on-going and necessary transition } \\
\text { pathways for key domains relevant for EU policy. }\end{array}$ & https://www.pathways-project.nl/ \\
\hline $\begin{array}{l}\text { ARTS } \\
\text { (Accelerating and Rescaling } \\
\text { Transitions to Sustainability) }\end{array}$ & $\begin{array}{l}\text { Led by DRIFT (Dutch Research Institute For } \\
\text { Transitions) and committed to understanding the } \\
\text { role and impact of transition initiatives in cities and } \\
\text { examining the conditions that can aid accelerating } \\
\text { change towards a sustainable low-carbon society. }\end{array}$ & http://acceleratingtransitions.eu/ \\
\hline \multicolumn{3}{|c|}{ Participative research projects } \\
\hline $\begin{array}{l}\text { ClimAdaPT.Local } \\
\text { (Municipal strategies for } \\
\text { Climate Change in Portugal) }\end{array}$ & $\begin{array}{l}\text { Had the goal of starting in Portugal a continuous } \\
\text { process leading to the elaboration of Municipal } \\
\text { Strategies for Adaptation to Climate Change } \\
\text { (Estratégias Municipais de Adaptação às } \\
\text { Alterações Climáticas - EMAAC, in Portuguese) } \\
\text { and its integration in municipal planning tools. }\end{array}$ & http://climadapt-local.pt/en/ \\
\hline $\begin{array}{l}\text { CCIAM } \\
\text { (Climate Change Impacts } \\
\text { Adaptation \& Modelling) }\end{array}$ & $\begin{array}{l}\text { Is a research group of the Faculty of Science of } \\
\text { Lisbon university. Its research areas are climate } \\
\text { change impact assessment, adaptation strategies } \\
\text { and the development of downscaled climate } \\
\text { scenarios, bringing together scientists from several } \\
\text { disciplines who conduct trans-disciplinary research } \\
\text { on both national and international level. }\end{array}$ & $\begin{array}{l}\text { http://ce3c.ciencias.ulisboa.pt/team/CCI } \\
\text { AM }\end{array}$ \\
\hline 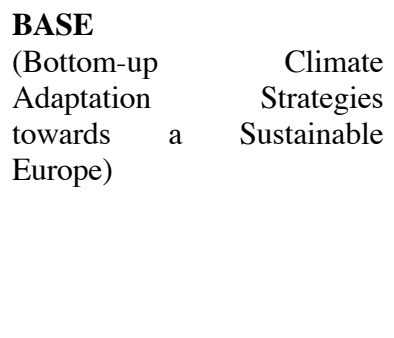 & $\begin{array}{l}\text { Addresses the need for research on sustainable } \\
\text { climate adaptation strategies, which promote } \\
\text { interactions between bottom-up and top-down } \\
\text { assessments. Its intention is to evaluate the } \\
\text { environmental, social and economic impacts, the } \\
\text { costs and benefits, policy coherence and } \\
\text { stakeholder perceptions of different climate } \\
\text { adaptation pathways from an interdisciplinary } \\
\text { perspective. }\end{array}$ & $\begin{array}{l}\text { http://ce3c.ciencias.ulisboa.pt/research/ } \\
\text { projects/ver.php?id=24 }\end{array}$ \\
\hline $\begin{array}{l}\text { Adapt for Change } \\
\text { (Improve the success of } \\
\text { reforestation in semi-arid } \\
\text { areas: adaptation to climate } \\
\text { change scenario) }\end{array}$ & $\begin{array}{l}\text { With the goal to decrease the cost-benefit of } \\
\text { reforestations through an innovative approach: - } \\
\text { Developing a model that points which areas: i) may } \\
\text { be easily and cheaply regenerated; ii) must be } \\
\text { subject to assisted reforestation, with the support of } \\
\text { different methods; iii) must be occupied by } \\
\text { alternative activities because of the difficulty in } \\
\text { reforestation. }\end{array}$ & $\begin{array}{l}\text { http://ce3c.ciencias.ulisboa.pt/research/ } \\
\text { projects/ver.php?id=42 }\end{array}$ \\
\hline
\end{tabular}




\begin{tabular}{|c|c|c|}
\hline $\begin{array}{l}\text { PLACARD } \\
\text { (PLAtform for } \\
\text { Adaptation } \\
\text { reDuction) }\end{array}$ & $\begin{array}{l}\text { With the mission to be the recognised platform for } \\
\text { dialogue, knowledge exchange and collaboration } \\
\text { between the Climate Change Adaptation (CCA) and } \\
\text { Disaster Risk Reduction (DRR) communities. }\end{array}$ & $\begin{array}{l}\text { https://climate- } \\
\text { adapt.eea.europa.eu/metadata/projects/p } \\
\text { latform-for-climate-adaptation-and-risk- } \\
\text { reduction }\end{array}$ \\
\hline \multicolumn{3}{|l|}{ CBI databases for Portugal } \\
\hline 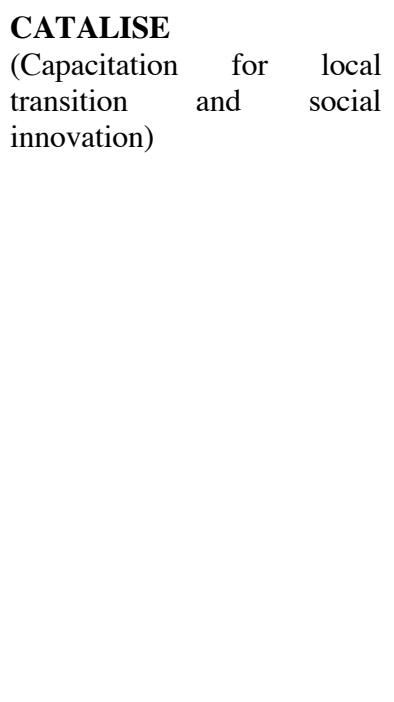 & $\begin{array}{l}\text { Was an interdisciplinary research project on socio- } \\
\text { ecological experimentation towards participation in } \\
\text { sustainable and integral local development. In a } \\
\text { nutshell, this project aggregated and analysed } \\
\text { available information on Portuguese CBIs from } 10 \\
\text { subnational networks, who seem to work } \\
\text { independently from each other and even have } \\
\text { access to smaller networks beneath them. These are, } \\
\text { for example, Fórum Cidadania \& Território, } \\
\text { ANIMAR - Associação Portuguesa para o } \\
\text { Desenvolvimento Local, Rede de projetos apoiados } \\
\text { pelo Portal da Economia Social Zoom da CASES or } \\
\text { Rede Convergir. It is explained that they also drew } \\
\text { on contacts from sub-networks with non-probability } \\
\text { (exponential snowball) sampling, out of their direct } \\
\text { control, to be able to reach out to all CBIs on the } \\
\text { ground, since many of them are in fact not } \\
\text { represented in networks (Marques and Balsa et al., } \\
\text { 2016: 33). }\end{array}$ & $\begin{array}{l}\text { http://ce3c.ciencias.ulisboa.pt/research/ } \\
\text { projects/ver.php?id=25 } \\
\text { Santos et al. (2015), Rocha et al. (2015) } \\
\text { or Marques Balsa et al. (2016) for } \\
\text { respective policy or research documents }\end{array}$ \\
\hline $\begin{array}{l}\text { Rede Convergir } \\
\text { (Convergence network) }\end{array}$ & $\begin{array}{l}\text { Is a hub website active since } 2011 \text { listing all } \\
\text { currently operating CBIs in Portugal, including an } \\
\text { event-calendar. It was initiated by several } \\
\text { individuals active in both sustainability research or } \\
\text { in CBIs on the ground, with the aim to create a } \\
\text { network for sustainability initiatives. }\end{array}$ & https://www .redeconvergir.net/ \\
\hline $\begin{array}{l}\text { Ecolise } \\
\text { (the European network for } \\
\text { community-led initiatives on } \\
\text { climate change and } \\
\text { sustainability) }\end{array}$ & $\begin{array}{l}\text { Is a coalition of national and international networks } \\
\text { of community-led initiatives on sustainability and } \\
\text { climate change, as well as organizations that } \\
\text { support a community-led transition to a resilient } \\
\text { Europe. }\end{array}$ & https://www.ecolise.eu/ \\
\hline
\end{tabular}




\section{References}

Alexander, S., Rutherford, J., 2014. The deep green alternative: Debating strategies of transition. Simplicity Institute Report 14a, 1-24.

Ancona, D. (2012). Framing and Acting in the Unknown. S. Snook, N. Nohria, \& R. Khurana, The Handbook for Teaching Leadership, 3-19.

Anguelovski, I., Carmin, J., 2011. Something borrowed, everything new: innovation and institutionalization in urban climate governance. Current opinion in environmental sustainability 3 (3), 169-175. https://doi.org/10.1016/j.cosust.2010.12.017.

Argüelles, L., Anguelovski, I., Dinnie, E., 2017. Power and privilege in alternative civic practices: Examining imaginaries of change and embedded rationalities in community economies. Geoforum, 86, 30-41. https://doi.org/10.1016/j.geoforum.2017.08.013

Avelar, D., Coelho, R., Garrett, P., Penha Lopes, G., 2018. Rede CONVERGIR in numbers. Lisbon, Rede Convergir. Unpublished manuscript.

Avelino, F., Rotmans., J., 2009. Power in transition: an interdisciplinary framework to study power in relation to structural change. European Journal of Social Theory 12 (4), 543-569. https://doi.org/10.1177/1368431009349830.

Avelino, F., Wittmayer, J.M., 2016. Shifting power relations in sustainability transitions: a multi-actor perspective. Journal of Environmental Policy \& Planning 18 (5), 628-649. https://doi.org/10.1080/1523908X.2015.1112259.

Barry, J., Quilley, S., 2009. The transition to sustainability: Transition towns and sustainable communities. In: The Transition to Sustainable Living and Practice, Emerald Group Publishing Limited, 1-28.

Baumgarten, B., 2017. Back to Solidarity-Based Living? The Economic Crisis and the Development of Alternative Projects in Portugal. University of Salento. DOI Code: 10.1285/i20356609v10i1p169.

Becker, S.L., Franke, F., Gläsel, A., 2018. Regime pressures and organizational forms of community-based sustainability initiatives. Environmental Innovation and Societal Transitions, 29, 5-16. https://doi.org/10.1016/j.eist.2017.10.004.

Berkes, F., 2004. Rethinking community-based conservation. Conservation biology 18 (3), 621-630. https://doi.org/10.1111/j.1523-1739.2004.00077.x 
Blühdorn, I., 2007. Sustaining the unsustainable: Symbolic politics and the politics of $\begin{array}{lllll}\text { simulation. } & \text { Environmental } & \text { politics } & 16 & \text { (2), 251-275. }\end{array}$ https://doi.org/10.1080/09644010701211759.

Brown, K., 2017. Global environmental change II: Planetary boundaries-A safe operating space for human geographers? Progress in Human Geography 41 (1), 118-130. https://doi.org/10.1177/0309132515604429

Campos, I., Vizinho, A., Truninger, M., Penha Lopes, G., 2016. Converging for deterring land abandonment: a systematization of experiences of a rural grassroots innovation. Community Development Journal, 51(4), 552-570. https://doi.org/10.1093/cdj/bsv051 Carlsson, L., 2000. Policy networks as collective action. Policy Studies Journal 28, 502-520. https://doi.org/10.1111/j.1541-0072.2000.tb02045.x.

Celata, F., Coletti, R., 2018. The policing of community gardening in Rome. Environmental Innovation and Societal Transitions, 29, 17-24.

DuPuis, M., Goodman, D., 2005. Should we go "home" to eat?: toward a reflexive politics of localism. Journal of rural studies 21(3), 359-371.

Ecolise, (n.d.). Map of initiatives (literally) [Geo-referenced map with content]. Available at www.ecolise.eu/map-of-initiatives [Accessed on July 20th 2018].

Esteves, A. M., 2017. "Commoning" at the borderland: ecovillage development, socioeconomic segregation and institutional mediation in southwestern Alentejo, Portugal. Journal of Political Ecology, 968-991. http://hdl.handle.net/10071/14297.

Fernandes-Jesus, M., Carvalho, A., Fernandes, L., Bento, S., 2017. Community engagement in the Transition movement: views and practices in Portuguese initiatives. Local Environment 22 (12), 1546-1562. https://doi.org/10.1080/13549839.2017.1379477.

Frantzeskaki, N., Rok, A., 2018. Co-producing urban sustainability transitions knowledge with community, policy and science. Environmental Innovation and Societal Transitions, In Press. https://doi.org/10.1016/j.eist.2018.08.001.

Geels, F., Schot, J. 2007. Typology of sociotechnical transition pathways. Research Policy 36, 399-417. https://doi.org/10.1016/j.respol.2007.01.003.

Geels, F., 2011. The multi-level perspective on sustainability transitions: Responses to seven criticisms. Environmental innovation and societal transitions 1 (1), 24-40. https://doi.org/10.1016/j.eist.2011.02.002. 
Göpel, M, 2016. The Great Mindshift. Vol. 2. Springer Verlag. https://doi.org/10.1007/9783-319-43766-8.

Göpel, M, 2017. Shedding some light on the invisible: the transformative power of paradigm shifts. Wuppertal Institut.

Hart, S.L., Milstein, M.B., 2003. Creating sustainable value. Academy of Management Perspectives, 17 (2), 56-67. https://doi.org/10.5465/ame.2003.10025194.

Haxeltine, A., Pel, B., Dumitru, A., Avelino, F., Kemp, R., Bauler, T., Jørgensen, M.S., 2017. Towards a TSI theory: a relational framework and 12 propositions. TRANSIT working paper 16. TRANSIT: EU SSH.2013.3.2-1 Grant agreement no: 613169.

Henfrey, T., Penha-Lopes, G., 2018. Policy and community-led action on sustainability and climate change: Paradox and possibility in the interstices. Environmental Innovation and Societal Transitions, in Press. https://doi.org/10.1016/j.eist.2018.05.002.

Hof, A., Berg, H., Frantzeskaki, N., Holsten, A., van Vuuren, D., Maschmeyer, S., Silvestri, G., Loorbach, D., n.d.. Beyond upscaling? Multiple pathways to accelerate sustainability transitions. Common Policy Brief of the TESS, PATHWAYS and TRANSIT research projects. http://www.tess-transition.eu/wp-content/uploads/2017/01/Common-Policy-BriefUpdated.pdf [Accessed on May 2nd 2018].

Holsten A., Berg, H., Frantzeskaki, N., Hof, A., Maschmeyer, S., n.d.. Tracing impact and showcasing success of transition initiatives. Common Policy Brief of the TESS, PATHWAYS and TRANSIT research projects. http://www.tess-transition.eu/wpcontent/uploads/2017/01/Common-Policy-Brief-Updated.pdf [Accessed on May 2nd 2018]. IPBES, 2019. Summary for policymakers of the global assessment report on biodiversity and ecosystem services of the Intergovernmental Science-Policy Platform on Biodiversity and Ecosystem Services. Advance Unedited Version from $6^{\text {th }}$ of May 2019. https://www.ipbes.net/system/tdf/spm_global_unedited_advance.pdf?file=1\&type=node $\& \mathrm{i}$ $\mathrm{d}=35245$ [Accessed on May 8th 2019].

IPCC, 2018. Summary for Policymakers. In: Global Warming of $1.5^{\circ} \mathrm{C}$. An IPCC Special Report on the impacts of global warming of $1.5^{\circ} \mathrm{C}$ above pre-industrial levels and related global greenhouse gas emission pathways, in the context of strengthening the global response to the threat of climate change, sustainable development, and efforts to eradicate poverty [Masson-Delmotte, V., P. Zhai, H.-O. Pörtner, D. Roberts, J. Skea, P.R. Shukla, A. 
Pirani, W. Moufouma-Okia, C. Péan, R. Pidcock, S. Connors, J.B.R. Matthews, Y. Chen, X. Zhou, M.I. Gomis, E. Lonnoy, T. Maycock, M. Tignor, and T. Waterfield (eds.)]. World Meteorological Organization, Geneva, Switzerland.

Jackson, T., 2009. Prosperity Without Growth. Economics for a Finite Planet. London (Earthscan).

Kemp, R., Loorbach, D., Rotmans, J., 2007. Transition management as a model for managing processes of co-evolution towards sustainable development. The International Journal of Sustainable Development \& World Ecology 14, 78-91. https://doi.org/10.1080/13504500709469709.

Laclau, E., Mouffe, C., 2014. Hegemony and socialist strategy: Towards a radical democratic politics. Verso Trade.

Lazarus, R. J., 2008. Super wicked problems and climate change: Restraining the present to liberate the future. Cornell L. Rev., 94, 1153.

Leal, D., 2014. "Neo-Rural settlements in continental Portugal: Threaths and opportunities for rural planning." https://fenix.tecnico.ulisboa.pt/downloadFile/395146462980/ExtAbstract_DSL48455.pdf [Accessed on June 15th 2018].

Levin, K, Cashore, B., Bernstein, S., Auld, G., 2007. Playing it forward: Path dependency, progressive incrementalism, and the 'Super Wicked' problem of global climate change. In International Studies Association 48th Annual Convention. Chicago, February.

Levin, K, Cashore, B., Bernstein, S., Auld, G., 2012. Overcoming the tragedy of super wicked problems: constraining our future selves to ameliorate global climate change. Policy sciences 45 (2), 123-152. https://doi.org/10.1007/s11077-012-9151-0.

Markard, J., Raven, R., Truffer, B., 2012. Sustainability transitions: An emerging field of research and its prospects. Research policy 41 (6), 955-967. https://doi.org/10.1016/j.respol.2012.02.013.

Marques Balsa, C., Albuquerque, C., Avelar, D., Penha Lopes, G., Nolasco, M., Santos, P., Rocha, S., 2016. Experimentação Socioecológica: Novos caminhos para a participação no desenvolvimento local sustentável e integral. Relatório Científico do Projeto de Investigação CATALISE. Lisbon. http://www.redeconvergir.net/public/catalise-relatorio-cientifico.pdf [Accessed on May 2nd 2018] 
Mason, K., Whitehead, M., 2012. Transition Urbanism and the Contested Politics of Ethical Place Making. Antipode, 44 (2), 493-516. https://doi.org/10.1111/j.14678330.2010.00868.x.

McLeroy, K.R., Norton, B.L., Kegler, M.C., Burdine, J.N., Sumaya, C.V., 2003. Community-Based Interventions. American Journal of Public Health 93 (4), 529-533.

Minkoff, D.C., 1997. The sequencing of social movements. American Sociological Review 62, 779-799. DOI: $10.2307 / 2657360$.

Moghaddam, F., 2010. Commentary: Intersubjectivity, interobjectivity, and the embryonic fallacy in developmental science. Culture \& psychology 16 (4), 465-475.

Montoya, J.M., Donohue, I., Pimm, S.L., 2018. Planetary boundaries for biodiversity: implausible science, pernicious policies. Trends in ecology \& evolution 33 (2), 71-73. https://doi.org/10.1016/j.tree.2017.10.004.

Moscovici, S., 1979. La representación social: un concepto perdido. El Psicoanálisis, su imagen y su público 2, 27-44.

Mourato, J., Bussler, A., Krauz, A., Truninger, M., 2018. Framing the Alternative: Sociopolitical Dynamics towards Sustainability. In: Delicado, A., Domingos, N., Sousa, L. (Eds.), Changing Societies, Legacies and Challenges (3) - The diverse worlds of sustainability. Imprensa das Ciências Sociais, Lisbon. https://doi.org/10.31447/ics9789726715054.03.

Olsson, P., Gunderson, L.H., Carpenter, S.R., Ryan, P., Lebel, L., Folke, C., Holling, C.S., 2006. Shooting the rapids: navigating transitions to adaptive governance of social-ecological systems. Ecology and Society 11 (1), 18.

Olsson, P., Moore, M., Westley, F., Mc Carthy, D., 2017. The concept of the Anthropocene as a game-changer: a new context for social innovation and transformations to sustainability. Ecology and Society 22 (2), 31. https://doi.org/10.5751/ES-09310-220231.

O'Riordan, T., 2014. Sustainability beyond austerity: possibilities for a successful transition to a wellbeing society. Análise Social 211, 497-520.

Palonen, K., 2003. Four times of politics: Policy, polity, politicking, and politicization. Alternatives 28 (2),171-186.

Patterson, J., Schulz, K., Vervoor, J., Van Der Hel, S., Widerberg, O., Adler, C., et al., 2017. Exploring the governance and politics of transformations towards sustainability. 
Environmental Innovation and Societal Transitions 24, 1-16. https://doi.org/10.1016/j.eist.2016.09.001.

Pel, B., Bauler. T., 2014. The institutionalization of social innovation: between transformation and capture. TRANSIT working paper 2 .

Pelling, M., High, C., Dearing, J., Smith, D., 2008. Shadow spaces for social learning: A relational understanding of adaptive capacity to climate change with organisations. Environment and Planning A 40 (4), 867-884. https://doi.org/10.1068/a39148.

Prugh, T., Costanza, R., Daly, H., 2000. The local politics of global sustainability. Island Press.

Rede Convergir, n.d.. Mapa de Iniciativas (literally) [Geo-referenced map with content]. WWw.redeconvergir.net [Accessed on May 4th 2018].

Retolaza, I.E., 2011. Theory of Change. A thinking and action approach to navigate in the complexity of social change processes. UNDP/HIVOS.

Rickards, L., 2015. Critiquing, mining and engaging Anthropocene science. Dialogues in Human Geography 5 (3), 337-342. https://doi.org/10.1177/2043820615613263.

Rocha, S., Albuquerque, C., Nolasco, M., Santos, P., Avelar, D., Penha-Lopes, G., 2016. Iniciativas de Experimentação Socio-Ecológica. Caderno de Recomendações Sociais e de Política. Capacitação para a Transição Local e Inovação Social, Lisbon. http://www .redeconvergir.net/public/catalise-caderno-recomendacoes-web.pdf [Accessed on May 2nd 2018].

Rotmans, J., Loorbach, D., 2009. Complexity and transition management. Journal of Industrial Ecology 13 (2), 184-196. https://doi.org/10.9774/GLEAF.9781315717289_14.

Santos, P., Rocha, S., Nolasco, M., Avelar, D., Albuquerque, C., Penha-Lopes, G., 2016. Iniciativas de Experimentação SocioEcológica: Guia de Práticas de Transformação, Lisboa. http://www .redeconvergir.net/public/catalise-guia-praticas-web.pdf [Accessed on May 2nd 2018].

Schmidt, L., Nave, J.G., Guerra, J., 2006. Who's afraid of Local Agenda 21? Top-down and bottom-up perspectives on local sustainability. International Journal of Environment and Sustainable Development 5 (2), 181-198. http://hdl.handle.net/10451/22504. 
Seyfang, G., Haxeltine, A., 2012. Growing grassroots innovations: exploring the role of community-based initiatives in governing sustainable energy transitions. https://doi.org/10.1068/c10222.

Smith, A., Stirling, A., Berkhout, F., 2005. The governance of sustainable socio-technical transitions. Research policy 34 (10), 1491-1510.

Smith, A., Hargreaves, T., Hielscher, S., Martiskainen, M., Seyfang, G., 2016. Making the most of community energies: Three perspectives on grassroots innovation. Environment and Planning A, 48 (2), 407-432. http://doi.org/10.1177/0308518X15597908.

Steffen, W., Richardson, K., Rockström, J., Cornell, S. E., Fetzer, I., Bennett, E. M., Biggs, R., Carpenter, S., de Vries, W., de Wit, C., Folke, C., Gerten, D., Heinke, J., Mace, G., Persson, L., Ramanathan, V., Reyers, B., Sörlin, S., 2015. Planetary boundaries: Guiding human development on a changing planet. Science 347 (6223). DOI: 10.1126/science.1259855.

Swyngedouw, E., 2010. Apocalypse forever? Post-political populism and the spectre of climate change. Theory, Culture \& Society $27 \quad(2-3, \quad 213-232$. https://doi.org/10.1177/0263276409358728.

Swyngedouw, E., 2011. The non-political politics of climate change. Acme 12 (1), 1-8.

TESS, n.d.. Success Factors of Community-based Sustainability Initiatives - Results from TESS. Policy Brief from the TESS research project. http://www.tess-transition.eu/wpcontent/uploads/2016/10/Tess_draft_Policy-Brief_success_1-1.pdf [Accessed on June 15th 2018]. 